\section{Effect of Cover Crops on Yield and Leaf Nutrient Concentrations in an Organic Honeycrisp Apple (Malus domestica 'Honeycrisp') Orchard in Nova Scotia, Canada}

\author{
Mehdi Sharifi ${ }^{1}$ \\ Canada Research Chair in Sustainable Agriculture, School of Environment, \\ Trent University, Peterborough, ON K9J 7B8, Canada
}

Julia Reekie

Atlantic Food and Horticulture Research Centre, Agriculture and Agri-Food Canada, Kentville, NS B4N 1J5, Canada

Andrew Hammermeister and Mohammed Zahidul Alam

Department of Plant and Animal Sciences, Faculty of Agriculture, Dalhousie University, Truro, NS B2N 5E3, Canada

\section{Taylor MacKey \\ Sustainability MA Program, Trent University, Peterborough, ON K9J 7B8, Canada}

Additional index words. legumes, nutrient management, orchard floor management, Swiss Sandwich System, organic farming

\begin{abstract}
There is an increasing interest for use of cover crops in orchards; however, the species that are most likely to be successfully implemented and their impact on yield and soil productivity have not been fully explored under Maritimes climate. This study investigated the effect of various cover crops treatments on organic apple (Malus domestica Borkh cv. Honeycrisp) yield and leaf nutrient concentrations in Nova Scotia over 3 years. Various cover crop mixtures including legumes, cereals, and grasses were planted using a modified Swiss Sandwich System (SSS). The cover crops treatments did not affect apple yield. In 2012, the input of biomass to the soil was $89 \%$ and $144 \%$ greater for alfalfa (ALF) and other cover crop treatments than unseeded (CON) treatment, respectively. The pea, oats, vetch mixture (POVM) contributed $24 \%$ higher biomass $N$ to soil compared with average of other cover crops in 2012. Soil available $K$ concentration in the tilled strip was increased in the 3rd year of the study compared with the initial values across cover crop treatments. The red clover oats mixture (RCOM), POVM, and Triple Mix (TM) treatments appeared to add the greatest amount of available $K$ to the soil among treatments. The CON, TM, and ALF treatments resulted in higher leaf Mn concentration in only 2012 and $C O N$, sweet clover and oats mixture (SCOM), and ALF resulted in higher leaf $P$ concentration in 2014, compared with other treatments. Cover crops did not compete with apple trees and their most beneficial and consistent contribution was to total $C$, total $N$, and $K$ input to the soil.
\end{abstract}

Received for publication 2 Feb. 2016. Accepted for publication 26 Aug. 2016

Funding was provided by NSERC Engage program.

The in-kind contribution from Boates Farms Limited is highly appreciated. Technical assistance was provided by Georgia Lewis and Chen Chen. Eric Specht and Ashley Smith helped set up experimental plots and tree/yield measurements. The help for statistical analysis was provided by Yeukai Katanda. Help from M. Reza Ardakani in initial organization of the manuscript is greatly appreciated. The support from nutrient management industrial research chair position previously held by Mehdi Sharifi at Faculty of Agriculture, Dalhousie University (former name: Nova Scotia Agricultural College), is also highly appreciated.

${ }^{1}$ Corresponding author. E-mail: mehdi.sharifi@ canada.ca. these amendments through the use of cover crops has the potential to reduce production costs for organic farms. Furthermore, cover crops have several other benefits including increasing soil organic matter and stimulating soil microbial activity (Neilsen et al., 2009; Yao et al., 2005). However, cover crops can also compete with fruit bearing trees for resources, negatively affecting yield, and fruit quality (Granatstein and Sanchez, 2009). For that reason there is a need to identify cover crops and residue management systems that will minimize competition with trees, while at the same time contributing to soil productivity.

Legume cover crops can provide $\mathrm{N}$ and have the potential to reduce or replace offfarm sources of $\mathrm{N}$ fertilizers (Smukler et al., 2012). Cover crops contribute to soil inorganic $\mathrm{N}$ and soil labile $\mathrm{N}$ pools. The $\mathrm{N}$ content of a legume cover crop can be as high as $240 \mathrm{~kg} \mathrm{~N} / \mathrm{ha}$, most of which is released in the first year after incorporation (Stark and Porter, 2005). Insufficient $\mathrm{N}$ supply results in poor plant growth, lower yields, and small fruit size (Neilsen and Neilsen, 2003), whereas excess $\mathrm{N}$ or late supply of $\mathrm{N}$ can negatively impact fruit quality by delaying maturity, or reducing firmness, and poor coloration (Kays, 1999; Marsh et al., 1996). Excess application of $\mathrm{N}$ will also increase the risk of $\mathrm{N}$ losses to the environment, especially in the humid temperate climate of eastern Canada. Provincial guides to cover crops for organic production in eastern Canada (OMAFRA, 2011a, 2011b) suggest, in addition to perennials like red clover (Trifolium pratense) and alfalfa (Medicago sativa L.), cover crops such as hairy vetch (Vicia villosa), sweet clover (Melilotus sp.), field peas (Pisum sativum L.), or their mixtures. Green manure options for organic producers are not limited to perennial leguminous crops (Munoz et al., 2005), and variability in tree $\mathrm{N}$ uptake response to a legume cover crop may also be attributed to the productivity of a cover crop, and timing of its incorporation into the soil (Messiga et al., 2016).

Determining cover crops that contribute to tree growth and fruit yield is important, especially in organic apple orchards. Cover crops have the potential to compete with trees for water and $\mathrm{N}$, and thus affect tree growth and fruit production (Kuhn and Pedersen, 2009). Sánchez et al. (2007) reported in a steady decline in organic apple leaf $\mathrm{N}$ for all their cover crops (alfalfa/fescue, strawberry clover, and vetch) and control treatments in Argentina when no supplemental source of nutrients was added. There are evidences to suggest that the long-term decline of soil health due to poor floor management may be more detrimental to productivity than cover crop competition during the initial orchard establishment (Atucha et al., 2011; Oliveira and Merwin, 2001; Yao et al., 2005). It has also been shown that the reduced yields during orchard establishment with cover crops are not sustained in the long-term and that trees eventually adapted and became more yield efficient than trees in herbicide 
treated weed-free system (Atucha et al., 2011). This is especially important for organic apple orchards aiming to increase their long-term sustainability.

There is also little information on the effects of different cover crops on organic apple yields. We hypothesized that cover crops will improve soil properties and will have no effect or positive effect on the organic orchard yield under the condition of the experiment. This study examined the impacts of different cover crops, or mixtures, using a modified SSS on apple yields, tree growth, and leaf nutrient concentrations in an organic apple orchard in Nova Scotia, Canada.

\section{Materials and Methods}

The study was conducted at Boates Farms Limited, a 10 ha certified organic apple farm in Woodville, Nova Scotia, Canada. The area is characterized by sandy and silt loam soil and a humid temperate climate with mean temperature of $12.4{ }^{\circ} \mathrm{C}$ and precipitation of about $724 \mathrm{~mm}$ during the growing season. The orchard was established in 2005, and a section with 'Honeycrisp' variety on 'EMLA 7' root system was chosen for this study. 'EMLA 7' rootstock is well suited in the Maritime region. Mature tree on this rootstock are semidwarfed reaching 3.7$4.6 \mathrm{~m}$ in height. This rootstock is desirable because it is winter hardy, fire-bright tolerant, provides good anchorage, and does well in most soils. As trees were crafted on 'EMLA 7' rootstock, which provides good anchorage, they are freestand reaching about $4 \mathrm{~m}$ tall. These semidwarf trees are spaced $2.4 \mathrm{~m}$ within a tree row and the alley width is $5.5 \mathrm{~m}$ between two tree rows.

Cover crops were planted using a modified SSS. The SSS is an apple orchard floor management system, which leaves a strip of vegetation to grow naturally in the tree row with two narrow strips maintained weed free by tillage on each side mostly used in Organic production (Schmid and Weibel, 2000; Stefanelli et al., 2009). The grassy strip acts as groundcover, which adds organic matter and nutrients through regular mowing. However, it can result in less suitable growing conditions for trees due to competition for water and nutrients. We proposed a modified SSS in this study. A narrow band, $0.5 \mathrm{~m}$, of goose grass (Galium aparine L.) in the tree line was left undisturbed. This goose grass strip was mowed twice each season using a grass trimmer when the grasses were over $0.5 \mathrm{~m}$ tall and touched the tree branches. Cover crops treatments were grown in a $3.5 \mathrm{~m}$ width in the alley with a $0.5 \mathrm{~m}$ wide unseeded tilled strip at both sides of goose grass strip. Tilling was done using a Trump tiller at $500 \mathrm{rpm}$ to the depth of 5-7 $\mathrm{cm}$. Cover crops in the alley were mowed, raked to tilled strip, and incorporated into the bare strip, thus the grassy strip in the tree row and cover crops in the alley area both adds organic matter and nutrients. Cover crop treatments and their seeding rates were as follows:
1) $\mathrm{CON}$ (control)

2) RCOM, at $6+80 \mathrm{~kg} \cdot \mathrm{ha}^{-1}$

3) POVM, at $100+80+20 \mathrm{~kg} \cdot \mathrm{ha}^{-1}$

4) $\mathrm{SCOM}$, at $5+80 \mathrm{~kg} \cdot \mathrm{ha}^{-1}$

5) TM: red clover, alsike clover and timothy grass, at $2.25+2.25+10.5 \mathrm{~kg} \cdot \mathrm{ha}^{-1}$

6) ALF at $25 \mathrm{~kg} \cdot \mathrm{ha}^{-1}$

The CON treatment was included to be able to monitor the soil $\mathrm{N}$ dynamics with and without cover crops. Each year, the seed germination rates were tested and the seeding rate adjusted for germination rate. Alleyways were shallowly cultivated with rotor tiller in early May to remove the previous vegetation. The cover crops were seeded twice in 2012, May 17 and June 13, and on 1 May 2014. The first cover crop seeding in 2012 was not successfully established, likely due to below 30 -year average precipitation. Cover crop treatments were not reseeded in 2013 due to labor and funding constraints. This was not a concern for perennial cover crops treatments (i.e., RCOM, SCOM, TM, and ALF); however, the annual cover crop treatment (POVM) was also able to reseed itself in 2013 due to the late mowing in 2012. Cover crop seeding rates were according to the recommendation of New Brunswick Department of Agriculture, Aquaculture and Fisheries (Government of New Brunswick, 2009).

Each plot consisted of a row of five trees: three study trees with a guard tree on each side in a randomized complete block design (similar cover crops on both sides of the tree line) with four replications. Seeding was done carefully so minimum crosscontamination of cover crops seeds between adjoining plots were occurred. Yield and trunk cross-sectional area (TCA) data were collected for each individual tree (12 experimental units for each treatment), whereas all other measurements were collected by plot.

All treatments received $2000 \mathrm{~kg} \cdot \mathrm{ha}^{-1} \cdot$ year $^{-1}$ (half of the recommended rate) Nutri-Wave ${ }^{T M}$ (NW), certified organic dehydrated pelletized poultry manure (4-1-2 analysis), in the unseeded tilled strips at the both side of goose grass strip as starter fertilizer in May. Cover crops were mowed (at about $6 \mathrm{~cm}$ height from the ground) twice in the season and the clippings were pushed to unseeded tilled strip by a tractor mounted rake and incorporated to top $5 \mathrm{~cm}$ of the tilled strips using a rototiller. The mowing dates for 2012 were 21 Aug. and 6 October; for 2013, were June 19 and July 20; and for 2014, were June 20 and July 19. Grass strip was mowed twice using a hand held mower when the grasses were over $0.5 \mathrm{~m}$ tall and touching the tree branches. Before each mowing date only in 2012 , three quadrats $\left(0.25 \mathrm{~m}^{2}\right)$ of cover crop sample were collected randomly from each plot. The samples were oven dried at $65{ }^{\circ} \mathrm{C}$ for $48 \mathrm{~h}$, dry weights were recorded. Plant tissue samples were ground and analyzed for total $\mathrm{N}$ concentration by the Dumas method using a LECO CNS-1000 analyzer (LECO Corporation, St. Joseph, MI). Cover crops N uptake was calculated by multiplying the biomass by $\mathrm{N}$ concentration. Cover crops biomass were not sampled in 2013 and 2014 due to labor and funding constraints.

Relative chlorophyll content was recorded using a SPAD-502 m (Spectrum Technologies Inc., Plainfield, IL) on four fully expanded leaves from four sides of each test tree at $1.3 \mathrm{~m}$ height in late July in 2012 and 2014. The SPAD readings were not recorded in 2013. Mature midshoot leaves (7-8 from each test tree, i.e., 21 to 24 from each plot) were collected on July 25th 2012 and 7 Aug. 2014 and analyzed for N, P, K, Ca, Mg, Fe, $\mathrm{Mn}, \mathrm{Cu}, \mathrm{Zn}$, and $\mathrm{B}$ after oven drying for $48 \mathrm{~h}$ at $65^{\circ} \mathrm{C}$ and grinding. Total leaf tissue $\mathrm{N}$ was analyzed by Dumas method using a LECO CNS-1000 analyzer. Other macro and micronutrients were extracted by the dry ash method (Westerman, 1990) and analyzed using a Varian 725-ES Radial ICP-OES inductively coupled plasma mass spectrometer (ICP).

Standard organic practices were used for weed, insect, and disease control (OMAFRA, 2016). The fruits were harvested in the last week of September each year. While harvesting, number and weights of total and marketable fruits from each of the test trees were recorded. A fruit was considered marketable based on acceptable fruit color, size, blemishes, and pest attack (insect and disease). The TCA was calculated from trunk circumference measured at $25 \mathrm{~cm}$ above graft union of each test tree as a measurement of growth of the previous year in April of each year. In 2012, before the start of the experiment, four composite soil samples consisting of eight cores from each of the four blocks were collected from the tilled strip area at $15 \mathrm{~cm}$ depth and initial soil properties were analyzed (Table 1). Micro and macronutrients except $\mathrm{N}$ were measured using a Varian 725 ES Radial ICP-OES after extraction with Mehlich-3 solution. In Apr. 2012, four soil core samples (one from each block) were also collected for bulk density calculation (Blake and Hartge, 1986). In 2013 (August) and 2014 (April and October), composite soil samples (eight cores from each plot) were taken from the tilled strip, and analyzed for soil $\mathrm{pH}$ and available $\mathrm{P}$ and $\mathrm{K}$.

Table 1. Mean values $(n=4)$ for soil characteristics at the start of experiment (Spring 2012).

\begin{tabular}{lc}
\hline Soil parameter & Value \\
\hline PH & $5.75(0.06)^{z}$ \\
Bulk density $\left(\mathrm{g} / \mathrm{cm}^{3}\right)$ & $1.37(0.32)$ \\
Organic matter $(\%)$ & $3.30(0.22)$ \\
$\mathrm{CEC}(\mathrm{meq} / 100 \mathrm{~g})$ & $9.28(0.46)$ \\
$\mathrm{P}\left(\mathrm{kg} \cdot \mathrm{ha}^{-1}\right)$ & $285(84.89)$ \\
$\mathrm{K}\left(\mathrm{kg} \cdot \mathrm{ha}^{-1}\right)$ & $175(20.05)$ \\
$\mathrm{Ca}\left(\mathrm{kg} \cdot \mathrm{ha}^{-1}\right)$ & $2,016(123.66)$ \\
$\mathrm{Mg}\left(\mathrm{kg} \cdot \mathrm{ha}^{-1}\right)$ & $288(6.99)$ \\
$\mathrm{S}\left(\mathrm{kg} \cdot \mathrm{ha}^{-1}\right)$ & $33(1.73)$ \\
$\mathrm{Al}(\mathrm{ppm})$ & $1,378(41.41)$ \\
$\mathrm{Fe}(\mathrm{ppm})$ & $168(13.60)$ \\
$\mathrm{Mn}(\mathrm{ppm})$ & $37(5.92)$ \\
$\mathrm{Cu}(\mathrm{ppm})$ & $24(6.01)$ \\
$\mathrm{Zn}(\mathrm{ppm})$ & $1.30(0.22)$ \\
$\mathrm{B}(\mathrm{ppm})$ & $<0.5(0.00)$ \\
\hline $\mathrm{CEC}$ &
\end{tabular}

$\mathrm{CEC}=$ cation exchange capacity.

${ }^{2}$ Values in brackets are SD. 
Each year, data were analyzed using MIXED procedure of SAS version 9.3 with replicates as random effects and cover crops as fixed effects except for soil properties that soil sampling dates were considered as a repeated effect. Tree location in the orchard and TCA were used as covariates for analyzing total apple numbers and apple yield. These covariates helped to account for soil variability and tree size. Differences among least square means for all treatment pairs were tested at a significance level of $P<0.10$. The $P<0.10$ was chosen over $P<0.05$ due to high variability of tested parameters and higher chance of capturing the differences. Yield efficiency was calculated using the total weight of apples produced divided by TCA of previous year. The yield data for each tree was analyzed individually for each study year due to different environmental conditions.

\section{Results}

Seasonal air temperature and precipitation. The 30-year average growing season rainfall for the area is $724 \mathrm{~mm}$. The first year of the study had rainfall only $86 \%$ of the 30 -year average, which resulted in a delay in the sowing of cover crops. The warmest months were July and August in all years, reaching temperatures of 20.9 and $21.7 ; 21.5$ and 19.1 ; 22.2 and $18.9^{\circ} \mathrm{C}$, respectively, whereas the 30 -year average was 19.6 and $19.1{ }^{\circ} \mathrm{C}$ for July and August, respectively.

Soil properties. Initial soil test results showed that soil $\mathrm{pH}$ was 5.7 , and recommended lime application at $6 \mathrm{Mg} \cdot \mathrm{ha}^{-1}$ to increase the $\mathrm{pH}$ to the desired 6.5 level (Table 1). Organic matter content of the soil was $3.3 \%$. Soil bulk density up to $30 \mathrm{~cm}$ depth was $1.37 \mathrm{~g} \cdot \mathrm{cm}^{-3}$. Cation exchange capacity of the soil was $9.28 \mathrm{meq} 100 \mathrm{~g} / \mathrm{soil}$.

Soil properties were measured in three sampling dates during the experiment (Aug. 2013, Apr. 2014, and Oct. 2014) in addition to initial soil sampling (Apr. 2012). Soil properties were unaffected by the treatments during the experiment except for available K. There was a significant difference between soil available $\mathrm{K}$ content among sampling dates, as well as among treatments across sampling dates (Fig. 1). The treatment by sampling date interaction was not significant. The Aug. 2013 sampling date had the highest soil K content. Both sample dates in 2014 showed higher soil $\mathrm{K}$ content when compared with the initial concentrations in 2012. The RCOM, POVM, and TM treatments appeared to increase soil available $\mathrm{K}$ (Fig. 1). The available $\mathrm{K}$ levels in TM were intermediate and not significantly different from RCOM, POVM, SCOM, or ALF, but higher than CON. The SCOM and ALF resulted in lower soil available $\mathrm{K}$ compared with POVM and SCOM and not different from CON.

Cover crops. Cover crop biomass and $\mathrm{N}$ content was only measured in 2012. Cover crop establishment was delayed, in 2012, due to a dry period with minimal precipitation during May. At first mowing date, dry matter (DM) yield ranged between 120 and $164 \mathrm{~g} \cdot \mathrm{m}^{-2}$, and $\mathrm{N}$ content ranged between $2.77 \%$ and $3.88 \%$ (Table 2). However, these values did not statistically differ among cover crop treatments including the unseeded treatment. The Amaranth sp. and Chenopodium album $\mathrm{L}$. weed species dominated the unseeded treatment. However, after first mowing, Amaranth sp. and C. album did not grow further and at second mowing date (first week

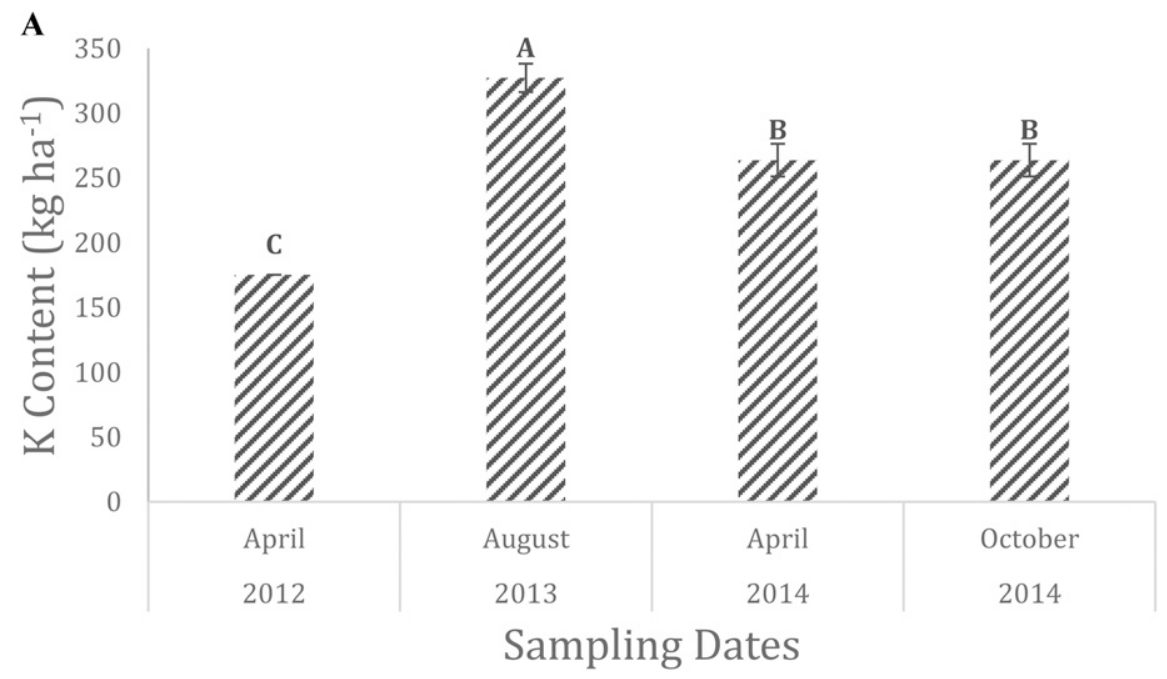

B

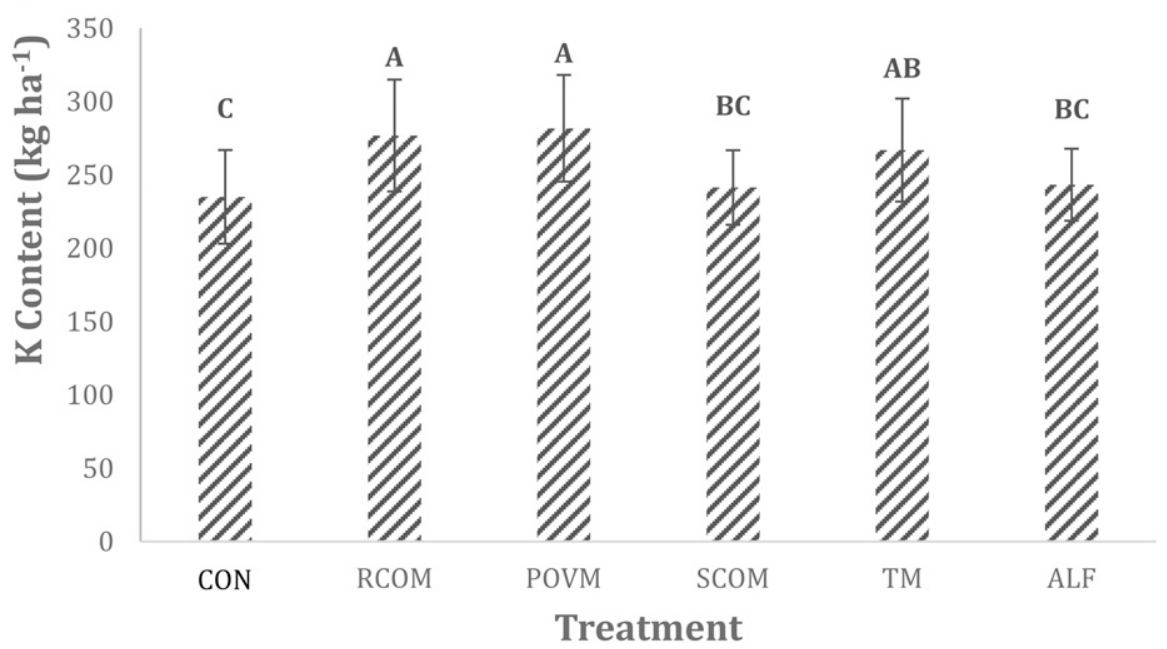

Fig. 1. (A) Mean soil available K concentrations by sampling dates. (B) Mean soil available K concentrations by treatment, bars with the same letter are not significantly different, $\alpha=0.1$. CON $=$ unseeded; RCOM $=$ red clover and oat mix; $\mathrm{POVM}=$ pea, oat, hairy vetch mix; $\mathrm{SCOM}=$ sweet clover and oat mix; $\mathrm{TM}=$ triple mix; ALF $=$ alfalfa.

Table 2. Cover crop dry matter yield and N contents in 2012.

\begin{tabular}{|c|c|c|c|c|c|c|}
\hline \multirow[b]{2}{*}{ Cover crop ${ }^{2}$} & \multicolumn{2}{|c|}{ First mowing } & \multicolumn{2}{|c|}{ Second mowing } & \multirow{2}{*}{$\begin{array}{l}\text { Total dry matter } \\
\left(\mathrm{Mg} \cdot \mathrm{ha}^{-1}\right)\end{array}$} & \multirow{2}{*}{$\begin{array}{l}\text { Plant } N \text { uptake } \\
\quad\left(\mathrm{kg} \cdot \mathrm{ha}^{-1}\right)\end{array}$} \\
\hline & $\overline{\mathrm{DW}}\left(\mathrm{g} \cdot \mathrm{m}^{-2}\right)$ & N (\%) & $\overline{\mathrm{DW}\left(\mathrm{g} \cdot \mathrm{m}^{-2}\right)}$ & $\overline{N(\%)}$ & & \\
\hline$\overline{\mathrm{CON}}$ & 131 & 3.88 & 0 & 0 & $0.84 \mathrm{c}$ & $32 \mathrm{c}$ \\
\hline RCOM & 151 & 2.77 & $159 b^{x}$ & $4.53 \mathrm{ab}$ & $1.98 \mathrm{a}$ & $72 \mathrm{~b}$ \\
\hline POVM & 129 & 3.17 & $219 a$ & $4.72 \mathrm{a}$ & $2.23 \mathrm{a}$ & $88 \mathrm{a}$ \\
\hline SCOM & 164 & 2.95 & $175 \mathrm{ab}$ & $4.09 \mathrm{c}$ & $2.17 \mathrm{a}$ & $76 \mathrm{~b}$ \\
\hline $\mathrm{TM}$ & 141 & 3.80 & $145 \mathrm{~b}$ & $4.17 \mathrm{bc}$ & $1.82 \mathrm{ab}$ & $73 \mathrm{~b}$ \\
\hline ALF & 120 & 3.33 & $129 \mathrm{~b}$ & $4.47 \mathrm{abc}$ & $1.59 \mathrm{~b}$ & $62 \mathrm{~b}$ \\
\hline $\begin{array}{c}\text { Analysis of } \\
\text { variance }\end{array}$ & NS & $P=0.072$ & $* * *$ & $* * *$ & $* * *$ & $* * *$ \\
\hline CV $(\%)$ & 16 & 17 & 23 & 7.0 & 14 & 8.7 \\
\hline
\end{tabular}

${ }^{{ }^{2} \mathrm{CON}}=$ unseeded RCOM $=$ red clover and oat mix; POVM $=$ pea, oat, hairy vetch mix; $\mathrm{SCOM}=$ sweet clover and oat mix; $\mathrm{TM}=$ triple Mix; $\mathrm{ALF}=$ alfalfa.

${ }^{\mathrm{y}} 64 \%$ of the alley way were used for calculation of cover crop dry matter.

${ }^{\mathrm{x}}$ Values in each column with the same letter are not significantly different at $0.05 P$ level using least square differences.

NS, *,**,**Nonsignificant or significant at $P \leq 0.05,0.01$, or 0.001 , respectively. Probability levels between 0.05 and 0.1 have been reported. 
of October), there were no weeds in the unseeded treatment at mowing height and other cover crop treatments were mostly weed free. At the second mowing date, significant differences were observed in DM production and $\mathrm{N}$ contents among cover crop treatments (Table 2). The highest DM yield in the second cut was recorded for POVM (219 $\left.\mathrm{g} \cdot \mathrm{m}^{-2}\right)$, which was comparable with SCOM (175 $\left.\mathrm{g} \cdot \mathrm{m}^{-2}\right)$. The RCOM, TM, and ALF had similar DM yields and were comparable with SCOM. The POVM had the highest $\mathrm{N}$ concentration $(4.7 \%)$ and it was comparable with RCOM (4.5\%). The SCOM had the lowest $\mathrm{N}$ concentration (4.1\%), which was comparable with TM and ALF. Highest values for total cover crops DM production were measured at POVM, SCOM, and RCOM followed by TM and ALF. Highest values for total cover crops $\mathrm{N}$ uptake were measured in POVM and total $\mathrm{N}$ uptake was not different among other cover crops treatments. The CON treatment had the lowest total DM and total $\mathrm{N}$ uptake. Taking into account that cover crops were grown in $64 \%$ of the alley area, 1.59 to $2.23 \mathrm{Mg} \cdot \mathrm{ha}^{-1} \mathrm{DM}$ and $62-88 \mathrm{~kg} \cdot \mathrm{ha}^{-1} \mathrm{~N}$ were made available to the orchard soil during 2012 growing season. The unseeded treatment received about 0.84 $\mathrm{Mg} \cdot \mathrm{ha}^{-1} \mathrm{DM}$ and $32 \mathrm{~kg} \cdot \mathrm{ha}^{-1} \mathrm{~N}$ through weeds biomass.

Leaf nutrient contents and SPAD measurements. Leaf tissue samples were only analyzed in 2012 and 2014. Leaf nutrient analysis showed that there was a significant difference among cover crops treatments for only $\mathrm{Mn}(P=0.083)$ in 2012 and only $\mathrm{P}(P=$ $0.008)$ in 2014. In 2012, the CON treatment had the highest concentration of Mn followed by TM and ALF, whereas the RCOM had the lowest (Fig. 2). The POVM and SCOM resulted in intermediate concentration of $\mathrm{Mn}$ in leaves. Sufficient levels of $\mathrm{Mn}$ are 25-200 ppm, which all of the treatments were within this range (OMAFRA, 2016). In 2014, the CON, SCOM, and ALF resulted in significantly higher leaf $\mathrm{P}$ concentration compared with RCOM (Fig. 2). The tissue P concentrations in POVM and TM were intermediate and not significantly different from RCOM or ALF. Sufficient levels of leaf tissue $P$ for fruit trees range from $0.15 \%$ to $0.26 \%$ (OMAFRA,

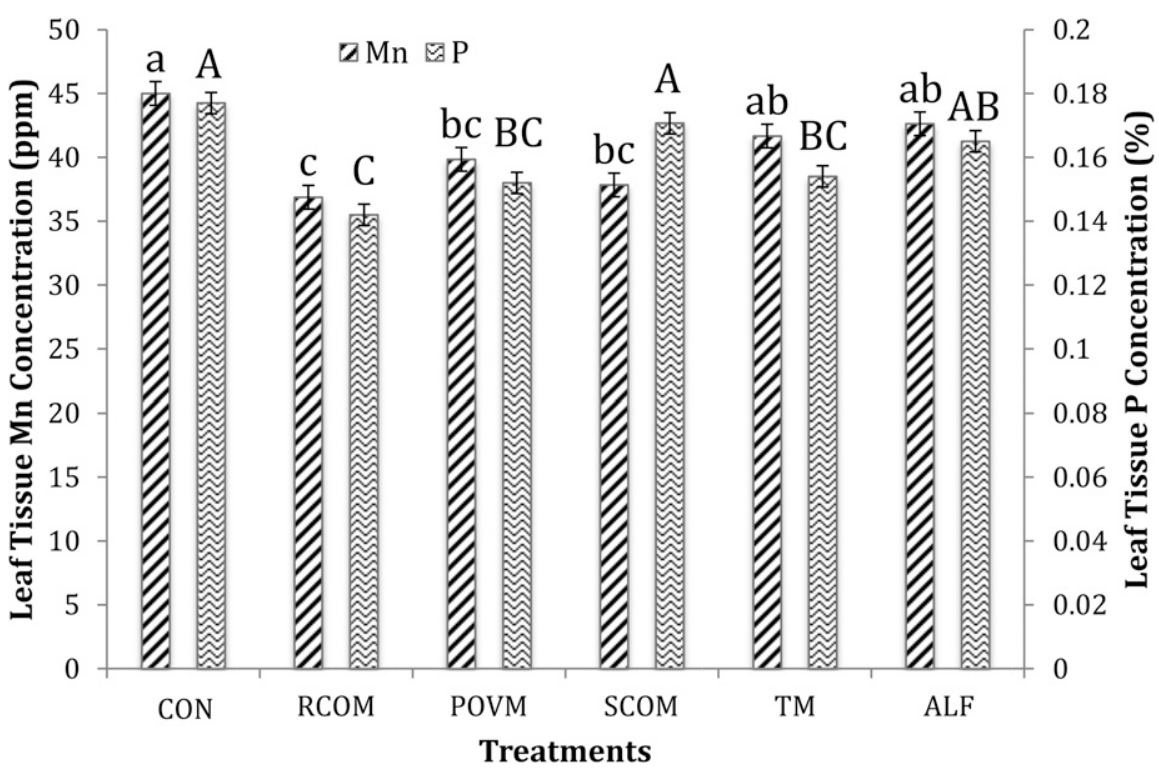

Fig. 2. Leaf tissue concentrations of $\mathrm{Mn}$ in 2012 and $\mathrm{P}$ concentrations in 2014 for all treatments. Bars with the same letter (capital letters used for P) are not significantly different within that year at $\alpha=0.1$. CON $=$ unseeded; RCOM = red clover and oat mix; POVM = pea, oat, hairy vetch mix; SCOM = sweet clover and oat mix; $\mathrm{TM}=$ triple mix; $\mathrm{ALF}=$ alfalfa.
2016), only the RCOM treatment was below the recommended range. SPAD measurements (only taken in 2012 and 2014) ranged from 45.0 to 46.8 in 2012 and from 39.2 to 42.5 in 2014 , and were not significantly affected by cover crop treatments (Table 3 ).

Marketable and unmarketable yield. Fruit yield (total or marketable) and yield efficiency were not significantly affected by cover crop treatments including $\mathrm{CON}$ (Table 3 ). Number of fruits per tree ranged from 53 to 86 across treatments in $2012,71-132$ in 2013, and 46-160 in 2014. The percentage of marketable yield to total yield on weight basis was $58 \%$ in $2012,65 \%$ in 2013 , and $82 \%$ in 2014 . Yield efficiency ranged from 0.76 to $1.07 \mathrm{~kg} \cdot \mathrm{cm}^{-2} \mathrm{TCA}$ in $2012,0.49$ to $0.90 \mathrm{~kg} \cdot \mathrm{cm}^{-2}$ TCA in 2013 , and 0.14 to 0.61 $\mathrm{kg} \cdot \mathrm{cm}^{-2}$ TCA in 2014. The highest mean yield efficiency was in 2012, followed by 2013, with 2014 having the lowest.

\section{Discussion}

Soil properties. Some of the impacts of cover crops on soil properties particularly nutrients might have been masked by addition of NW amendment in this study. The only significant difference between years or treatments on soil properties was soil available $\mathrm{K}$ content. Potassium affects fruit quality and yield for apples (Ernani et al., 2002). It is also an important nutrient for legumes, as low soil $\mathrm{K}$ availability can reduce $\mathrm{N}$ fixation (Duke et al., 1980). This was unlikely an issue in this study as an organic amendment (NW, 4-1-2) was applied. The two cover crops that produced the largest amount of total biomass (RCOM and POVM) in 2012 were also the treatments that had the highest soil K concentrations. Aug. 2013 soil samples had the highest soil $\mathrm{K}$ concentrations, although the $\mathrm{K}$ concentrations decreased for both sampling dates in 2014, which can likely be attributed to uptake of available $\mathrm{K}$ by cover crops. The spike in 2013 was likely due to the midseason sampling date, when the cover crops were cut and incorporated in the tilled strips. The increase in soil available $\mathrm{K}$ concentrations was seen in 2014 when compared with 2012. This increase could be due to the current and residual effect of NW application and residual effect of cover crop incorporation from the

Table 3. Analysis of variance and least square means for total apples, apple yield, yield efficiency and SPAD in 2012, 2013 , and 2014.

\begin{tabular}{|c|c|c|c|c|c|c|c|c|c|c|c|c|c|c|c|c|c|}
\hline Treatment $^{2}$ & \multicolumn{3}{|c|}{ Total apples/tree } & \multicolumn{3}{|c|}{$\begin{array}{c}\text { Unmarketable } \\
\text { apples/tree }\end{array}$} & \multicolumn{3}{|c|}{$\begin{array}{c}\text { Marketable } \\
\text { wt }(\mathrm{kg})\end{array}$} & \multicolumn{3}{|c|}{$\begin{array}{c}\text { Unmarketable } \\
\text { wt }(\mathrm{kg})\end{array}$} & \multicolumn{3}{|c|}{$\begin{array}{l}\text { Yield efficiency } \\
\quad\left(\mathrm{kg} \cdot \mathrm{cm}^{-2}\right)\end{array}$} & \multicolumn{2}{|c|}{ SPAD } \\
\hline$\overline{\mathrm{CON}}$ & 75 & 107 & 92 & 30 & 37 & 18 & 23 & 30 & 31 & 14 & 15 & 5 & 1.07 & 0.78 & 0.40 & 45.9 & 39.2 \\
\hline POVM & 53 & 132 & 46 & 22 & 59 & 21 & 16 & 32 & 9 & 11 & 25 & 2 & 0.80 & 0.85 & 0.14 & 45.6 & 39.5 \\
\hline SCOM & 56 & 99 & 53 & 23 & 34 & 10 & 13 & 33 & 20 & 11 & 13 & 4 & 0.76 & 0.90 & 0.36 & 46.0 & 40.1 \\
\hline $\mathrm{TM}$ & 86 & 71 & 160 & 40 & 29 & 40 & 20 & 20 & 36 & 17 & 10 & 8 & 1.03 & 0.49 & 0.55 & 45.8 & 42.4 \\
\hline ALF & 55 & 100 & 100 & 22 & 36 & 28 & 18 & 32 & 35 & 10 & 15 & 9 & 0.79 & 1.01 & 0.57 & 45.0 & 41.7 \\
\hline$P$ value & 0.341 & 0.125 & 0.171 & 0.119 & 0.267 & 0.263 & 0.301 & 0.318 & 0.301 & 0.225 & 0.143 & 0.29 & 0.625 & 0.142 & 0.649 & 0.610 & 0.162 \\
\hline
\end{tabular}

${ }^{2} \mathrm{CON}=$ unseeded; RCOM = red clover and oat mix; POVM = pea, oat, hairy vetch mix; SCOM = sweet clover and oat mix; TM = triple mix; $\mathrm{ALF}=$ alfalfa. $\mathrm{SPAD}$ data for 2013 were not collected. 
previous years. It is difficult to determine the $\mathrm{K}$ contribution of the cover crops as cover crops DM and their tissues $\mathrm{K}$ concentration were not determined in this study.

Cover crops. Cover crop establishment and consequently their DM and $\mathrm{N}$ contribution were limited by lower than normal precipitation in 2012. Cover crop data were not collected in subsequent years due to labor and budget constraints. Overall, in 2012, although POVM, SCOM, and RCOM performed comparatively better than other cover crops in terms of DM yield, POVM outperformed the other two in terms of total $\mathrm{N}$ uptake probably due to high protein contents in peas and vetch (Porter et al., 1999). The low ALF DM can be attributed to slow growth of alfalfa in the establishment year. At an apple orchard in New Zealand, it was estimated that $58 \mathrm{~kg} \cdot \mathrm{ha}^{-1} \mathrm{~N}$ was removed in the fruit and through leaching losses (Goh et al., 1995), whereas a clover cover crop provided nearly that much $\mathrm{N}$ in its biomass. This illustrates the potential for organic orchards to obtain a significant portion of their $\mathrm{N}$ needs through legume-based cover crops incorporation (Hoagland et al., 2008). Growing cover crops in the alley area may allow a large area for biomass production and symbiotic $\mathrm{N}$ fixation by legumes.

The amount and rate of $\mathrm{N}$ mineralized from cover crop residues has been shown to be dependent on the $\mathrm{C}: \mathrm{N}$ ratio of the residue, as well as environmental conditions such as moisture and temperature (Kuo and Sainju, 1998). Cover crop residues with lower C:N ratios $(\mathrm{C}: \mathrm{N}<20)$ will decompose more rapidly than those with higher ratios $(\mathrm{C}: \mathrm{N}>20)$ (Kuo and Sainju, 1998). The C:N ratios for different cover crops can range from 12:1 for sweet clover to 80:1 for timothy grass (Havlin et al., 2005). One study determined that POVM had an average C: $\mathrm{N}$ of 10.4:1 in Nova Scotia, Canada (M. Sharifi et al., unpublished data). Legumes have a low $\mathrm{C}: \mathrm{N}$ ratio and as a result rapidly decompose, given appropriate soil moisture and temperature (Abdul-Baki et al., 1997; Strivers and Shennan, 1991). This allows the $\mathrm{N}$ contained in these residues to become more quickly available to crops.

As a result of differing $\mathrm{C}: \mathrm{N}$ ratios in cover crops, it is important to synchronize the $\mathrm{N}$ release from cover crops with high orchard $\mathrm{N}$ demand to maximize $\mathrm{N}$ use efficiency and minimize losses though leaching and emissions. Cover crop residues would need to be incorporated in early July to allow adequate time for mineralization in humid temperate climate of Ontario, Canada. Soil moisture/ precipitation at this time will be a key factor influencing mineralization rate (DessureaultRompré et al., 2011). In the future, looking at the timing of incorporation could influence decisions on when to cut and incorporate cover crops. Although this would also have to take into account seeding as well as nutrient uptake and competition with orchard trees. The effect on the nutrient availability can be attributed to differences in BNF, root structure and depth, and affinity of the nutrient among cover crops species.
Leaf nutrient contents. Although there was a significant difference among some cover crops treatments for leaf Mn concentration in 2012, all leaf Mn concentration values were within the sufficiency range. Therefore, these differences are unlikely to have affected yield production or quality. Only the leaf $\mathrm{P}$ concentration in RCOM treatment fell below the recommended sufficiency levels for P; however, all of the treatments were in the lower end of the range. The RCOM treatment was the lowest for both $\mathrm{Mn}$ and $\mathrm{P}$ leaf concentrations.

Marketable and unmarketable yield. Yield efficiency may have been lowest in 2014 due to more unproductive trees than previous years (data not shown). There does not appear to be any recognizable trend between treatments and yield. Comparisons among years, for this short study, are also hampered by the Honeycrisp cultivars propensity for overcropping which results in strong biennial bearing (Crassweller et al., 2005; Embree and Nichols, 2005; Robinson and Watkins, 2003).

Yield efficiencies as high as $1.62 \mathrm{~kg} \cdot \mathrm{cm}^{-2}$ TCA and as low as $0.74 \mathrm{~kg} \cdot \mathrm{cm}^{-2}$ TCA have been demonstrated with Honeycrisp in one study in Nova Scotia (Wright et al., 2006). Another study, also in Nova Scotia, documented yield efficiencies ranging from 0.74 to $1.24 \mathrm{~kg} \cdot \mathrm{cm}^{-2}$ TCA (Braun et al., 2010). While the yield efficiencies in the current study were in the low end of these ranges, it is important to note that, unlike the current study, the previous examples are from conventional apple orchards and organic yields are generally lower.

There is other evidence to suggest that while different orchard floor management strategies might not affect fruit yield or quality in the short term, they have potential to improve soil properties and reduce erosion and nutrients losses to the environment (Neilsen et al., 2014; Oliveira and Merwin, 2001; Yao et al., 2005). Previous studies have reported that, in the long-term ( $>9$ years), apple trees will adapt to compensate for groundcover competition, and can even end up outperforming trees grown without groundcover (Atucha et al., 2011). It has also been previously postulated that maintaining groundcover free plots might result in the long-term deterioration of soil physical and biological conditions (Oliveira and Merwin, 2001; Yao et al., 2005), despite the short-term release of nutrients.

\section{Conclusions}

The different cover crops treatments did not affect apple yields in this study. Differences in tree growth and yield among the treatments may not have been large enough to be reflected in short-term. The spring application of poultry manure may also mask the effect of treatments. The use of cover crops in organic apple orchards contributes to soil organic matter and soil $\mathrm{N}$, and would not negatively affect yields under low input organic management. Based on establishment costs and biomass amount, perennial cover crops that include a mixture of legumes and grasses were found to be more suitable compared with annual cover crops for orchards in this region. Other than possible $\mathrm{N}$ contribution of legume-based cover crops, our findings showed that the cover crops can affect nutrient availability in soil. Future studies are needed to screen a wide range of cover crops species and their management for the effects on soil health, and orchard yield and yield quality in Atlantic Canada.

\section{Literature Cited}

Abdul-Baki, A.A., J.R. Teasdale, and R.F. Korcak. 1997. Nitrogen requirements of fresh-market tomatoes on hairy vetch and black polyethylene mulch. HortScience 32:217-221.

Atucha, A., I.A. Merwin, and M.G. Brown. 2011. Long-term effects of four groundcover management systems in an apple orchard. HortScience 46:1176-1183.

Blake, G.R. and K.H. Hartge. 1986. Bulk density, p. 363-375. In: A. Klute (ed.). Methods of soil analysis: Part 1: Physical and mineralogical methods. 2nd ed. Amer. Soc. of Agron., Madison, WI.

Braun, P.G., K.D. Fuller, K. McRae, and S.A. Fillmore. 2010. Response of 'Honeycrisp ${ }^{\circledR}$ ' apple trees to combinations of pre-plant fumigation, deep ripping, and hog manure compost incorporation in a soil with replant disease. HortScience 45:1702-1707.

Crassweller, R., R. McNew, A. Azarenko, B. Barritt, R. Belding, L. Berkett, and E. Stover. 2005. Performance of apple cultivars in the 1995 NE-183 regional project planting: Growth and yield characteristics. J. Amer. Pomol. Soc. $59: 18-27$

Dessureault-Rompré, J., B.J. Zebarth, A. Georgallas, D.L. Burton, M. Sharifi, G.A. Porter, G. Moreau, Y. Leclerc, W.J. Arsenault, T.L. Chow, and C.A. Grant. 2011. Prediction of soil nitrogen supply in potato fields using soil temperature and water content information. Soil Sci. Soc. Amer. J. 76:936-949.

Doran, J.W., M. Sarrantonio, and M.A. Liebig. 1996. Soil health and sustainability. Adv. Agron. 56:1-54.

Duke, S.H., M. Collins, and R.M. Soberalske. 1980 Effects of potassium fertilization on nitrogen fixation and nodule enzymes of nitrogen metabolism in alfalfa. Crop Sci. 20:213-219.

Embree, C.G. and D.S. Nichols. 2005. Bioregulators improve fruit size and colour and reduce crop-load and annual bearing of Honeycrisp $^{\mathrm{TM}}$ apples. Can. J. Plant Sci. 85:453-455.

Ernani, P.R., J. Dias, and J.A. Flore. 2002. Annual additions of potassium to the soil increased apple yield in Brazil. Commun. Soil Sci. Plant Anal. 33:1291-1304.

Goh, K.M., G.E. Ridgen, and M.J. Daly. 1995. Understory biomass production and biological nitrogen fixation in an organic apple orchard in Canterbury, New Zealand. Commun. Soil Sci. Plant Anal. 26:3261-3273.

Government of New Brunswick. 2009. Cover crops. 22 Jan. 2011. <http://www2.gnb.ca/content/dam gnb/Departments/10/pdf/Agriculture/CoverCrop. pdf $>$.

Granatstein, D. and K. Mullinix. 2008. Mulching options for Northwest organic and conventional orchards. HortScience 43:45-50.

Granatstein, D. and E. Sanchez. 2009. Research knowledge and need for orchard floor management in organic tree fruit systems. Intl. J. Fruit Sci. 9:257-281. 
Havlin, J.L., J.D. Beaton, S.L. Tisdale, and W.L. Nelson. 2005. Soil fertility and fertilizers: An introduction to nutrient management. 7 th ed. Pearson Education, Upper Saddle River, NJ.

Hoagland, L., L. Carpenter-Boggs, D. Granatstein, M. Mazzola, J. Smith, F. Peryea, and J.P. Reganold. 2008. Orchard floor management effects on nitrogen fertility and soil biological activity in newly established organic apple orchard. Biol. Fertil. Soils 45:11-18.

Kays, S.J. 1999. Preharvest factors affecting appearance. Postharvest Biol. Technol. 15:233-247.

Kuhn, B.F. and H.L. Pedersen. 2009. Cover crop and mulching effects on yield and fruit quality in unsprayed organic apple production. Eur. J. Hort. Sci. 74:247-253.

Kuo, S. and U.M. Sainju. 1998. Nitrogen mineralization and availability of mixed leguminous cover crop residues in soil. Biol. Fertil. Soils 26:346-353.

Marsh, K.B., M.J. Daly, and T.P. McCarthy. 1996. The effect of understory management on soil fertility, tree nutrition, fruit production and apple fruit quality. Biol. Agr. Hort. 13:161-173.

Messiga, A.J., K. Gallant, M. Sharifi, A. Hammermeister, K. Fuller, M. Tango, and S. Fillmore. 2016. Grape yield and quality response to cover crops and amendments in a vineyard in Nova Scotia, Canada. Amer. J. Enol. Viticult. 67:77-85.

Munoz, F., R.S. Mylavarapu, and C.M. Hutchinson. 2005. Environmentally responsible potato production systems: A review. J. Plant Nutr. 28:1287-1309.

Neilsen, G.H. and D. Neilsen. 2003. Nutritional requirements of apple, p. 267-302. In: D.C. Ferree and I.J. Warrington (eds.). Apples: Botany, production, and uses. CABI Publ., Cambridge, MA.
Neilsen, G.H., D.T. Lowery, T. Forge, and D. Neilsen. 2009. Organic fruit production in British Columbia. Can. J. Plant Sci. 89:677-692.

Neilsen, G., T. Forge, D. Angers, D. Neilsen, and E. Hogue. 2014. Suitable orchard floor management strategies in organic apple orchards that augment soil organic matter and maintain tree performance. Plant Soil 378:325-335.

Oliveira, M.T. and I.A. Merwin. 2001. Soil physical conditions in a New York orchard after eight years under different groundcover management systems. Plant Soil 234:233-237.

Ontario Ministry of Food, Agriculture and Rural Affairs (OMAFRA). 2011a. Field crop budgets. Publication 60. 22 Jan. 2011. <http:// www.omafra.gov.on.ca/english/busdev/facts/ pub60.htm\#2010>.

Ontario Ministry of Food, Agriculture and Rural Affairs (OMAFRA). 2011b. Cover crops. 22 Jan. 2011. <http://www.omafra.gov.on.ca/ english/crops/facts/cover_crops01/covercrops. htm>.

Ontario Ministry of Food, Agriculture and Rural Affairs (OMAFRA). 2016. Guide to fruit production. Publication 360. 12 Oct. 2015. <http:// www.omafra.gov.on.ca/english/crops/pub360/ pub360ch2.pdf $>$.

Porter, G.A., W.B. Bradbury, J.A. Sisson, G.B. Opena, and J.C. McBurnie. 1999. Soil management and supplemental irrigation effects on potato: I. Soil properties, tuber yield, and quality. Agron. J. 91:416-425.

Robinson, T.L. and C.B. Watkins. 2003. Cropload of Honeycrisp ${ }^{\mathrm{TM}}$ affects not only fruit size but many quality attributes. New York Fruit Qrtly. 11:7-10.

Sánchez, E.E., A. Giayetto, L. Cichón, D. Fernández, M.C. Aruani, and M. Curetti. 2007. Cover crops influence soil properties and tree performance in an organic apple (Malus domestica Borkh) orchard in northern Patagonia. Plant Soil 292: 193-203.

Schmid, A. and F. Weibel. 2000. Das SandwichSystem-ein Verfahren zur herbizidfreien Baumstreifenbewirtschaftung? [The Sandwich System, a procedure for herbicide free in-row weed control?] Obstbau. 25:214-217.

Smukler, S.M., A.T. O'Geen, and L.E. Jackson. 2012. Assessment of best management practices for nutrient cycling: A case study on an organic farm in a Mediterranean-type climate. J. Soil Water Conserv. 67:16-31.

Stark, J.C. and G.A. Porter. 2005. Potato nutrient management in sustainable cropping systems. Amer. J. Potato Res. 82:329-338.

Stefanelli, D., R.J. Zoppolo, R.L. Perry, and F. Weibel. 2009. Organic orchard floor management systems for apple effect on rootstock performance in the Midwestern United States. HortScience 44:263-267.

Strivers, L.J. and C. Shennan. 1991. Meeting the nitrogen needs of processing tomatoes through winter cover cropping. J. Prod. Agr. 4:330-335.

Westerman, R.L. 1990. Soil testing and plant analysis. 3rd ed. Soil Sci. Soc. Am. Madison, WI.

Wright, A.H., C.G. Embree, D.S. Nichols, R.K. Prange, P.A. Harrison, and J.M. Delong. 2006. Fruit mass, colour and yield of 'Honeycrisp' TM apples are influenced by manually-adjusted fruit population and tree form. J. Hort. Sci. Biotechnol. 81:397-401.

Yao, S.R., I.A. Merwin, G.W. Bird, G.S. Abawi, and J.E. Thies. 2005. Orchard floor management practices that maintain vegetative or biomass groundcover stimulate soil microbial activity and alter soil microbial community composition. Plant Soil 271:377-389. 